\title{
BOEKBESPREKING: MADE FOR TRADE - MADE IN CHINA
}

Op 30 november verdedigde Rosalien van der Poel haar proefschrift over Chinese exportschilderingen. Rosaliens liefde voor dit onderwerp is bekend. In 2006 en 2007 hield zij zich hiermee bezig tijdens een stage in Museum Volkenkunde en in 2008 rondde ze de studie kunstgeschiedenis af met een doctoraalscriptie over dit onderwerp. Publicaties verschenen onder andere in Aziatische Kunst en in het Bulletin van het Rijksmuseum. Het proefschrift is een voorlopig hoogtepunt van haar werk op dit terrein. Voorlopig, want we gaan nog veel van Rosalien horen.

Een waardevol onderdeel van het proefschrift vinden we in de laatste 25 pagina's: een lijst van alle Chinese exportschilderingen in Nederland.

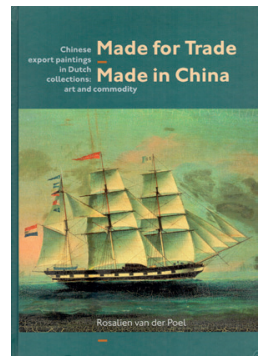
Van de aard en diversiteit daarvan krijgen we een indruk door het boek door te bladeren: circa 250 afbeeldingen van havengezichten, figuren in landschappen, schepen, vissen, bloemen, productiestadia van porselein, thee en zijde, beroepen van Chinezen, Chinezen uit verschillende delen van het keizerrijk en dat alles in een kleurrijke veelheid aan formaten en kwaliteiten.

Het proefschrift benadert dit corpus van buitenaf. Het gaat Rosalien erom het fenomeen Chinese exportschilderkunst betekenis te geven, om een methode te vinden de waarde van de schilderingen vast te stellen. Die waarde is nauw verbonden met de geschiedenis van de objecten, vanaf de vervaardiging in China, via de aankoop door Nederlandse kooplieden in Kanton, of later Shanghai, naar de eerste eigenaren in Nederland, hun nakomelingen en volgende eigenaren en soms museumcollecties. Steeds wisselt de aard en mate van de appreciatie. Het werk heeft vanzelfsprekend een (kunst)historische component, maar daarnaast worden benaderingswijzen uit de antropologie en de archeologie onderzocht en toegepast om de rijkgeschakeerde betekenis van de schilderingen nauwkeuriger te duiden.

De eerste theoretische hoofdstukken vereisen de nodige concentratie bij het lezen. Dat gold althans voor mij en heeft ermee te maken dat wij bij het museumwerk eigenlijk altijd met onze neus bovenop een object blijven zitten, waarover we vervolgens veilige, maar niet heel verstrekkende uitspraken doen. Rosalien heeft dat anders gedaan en stelt dat uitzoomen voor deze benadering noodzakelijk was. Dat is te begrijpen, en te waarderen, maar het gaat soms ver. Zo luidt de openingszin van hoofdstuk vijf over de culturele biografie van de schilderingen: 'Chinese export painting had a strong appeal to foreign powers active in the late eighteenth and mid nineteenth centuries.' Ik dacht dat foreign powers

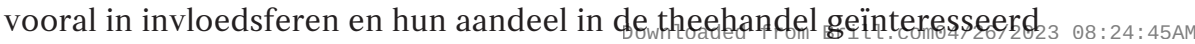




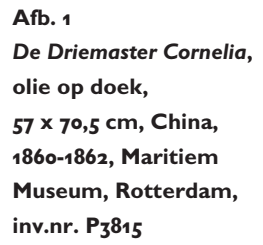

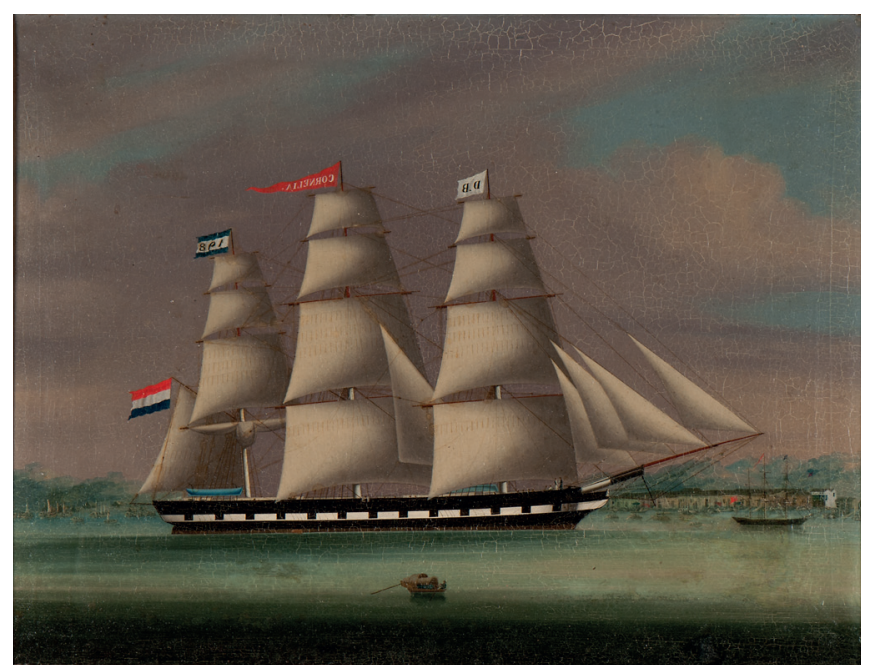

waren. Dat afzonderlijke functionarissen belangstelling hadden voor een Chinese schildering, voor zichzelf, voor thuis, om met winst te verkopen, dat zal zeker waar zijn, maar dat is dan waarschijnlijk weer niet waarnaar je als uitgezoomd onderzoeker op uit bent.

Allengs wordt het in datzelfde hoofdstuk echter veel concreter en wordt een aantal schilderingen zo gedetailleerd mogelijk gevolgd; van ontstaan tot - in sommige gevallen - geheel ingedommeld bestaan in een museumdepot. Wat ik bijzonder vind, is dat in een van die gevallen de dochter van een de verzamelaars kon worden geïnterviewd. Deze verzamelaars woonden van 1930 tot 1940 in Shanghai, Kobe en Tokyo en verzamelden daar Aziatische kunst waaronder ook Chinese exportschilderingen. Zo kon uit eerste hand opgetekend worden wat deze schilderingen betekenden voor de verzamelaars en nu voor hun kinderen.

In het laatste hoofdstuk zoomt Rosalien wederom in op de serie winterlandschappen in het Rijksmuseum voor Volkenkunde. Dit is een intrigerende groep schilderingen in olieverf op doek, steeds met groepen Chinezen in een kaal, bergachtig landschap. Het lijkt erop dat het in die schilderijen niet alleen winter, maar ook nacht is. Lijkt, schrijf ik, want de schilderijen zijn in een dergelijke deplorabele staat dat de donkerte ook te maken kan hebben met een laag vuil. Wie weet komt de zon op als ze gerestaureerd zijn. De vraag die zich opdringt is: wat is de band met Europese landschappen? Rosalien onderzoekt welke mogelijkheden Chinese schilders hadden om Europese bronnen te gebruiken, en in hoeverre er Chinese schildertradities bestaan waarin deze landschappen zich voegen. Het blijkt een moeilijk ontwarbare kluwen te zijn en deze schilderingen zijn dan ook bij uitstek voorbeelden van wat Rosalien in navolging van anderen 'EurAsian objects' noemt, voorwerpen die ontstaan zijn vanuit en dankzij de contacten tussen Azië en Europa. Het zijn objecten die een eigen categorie vormen die op de eigen merites moeten worden gewaardeerd en niet afhankelijk zijn van de mate waarin ze Europees dan wel Chinees zijn. Toegang tot de Europese

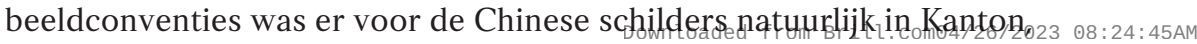




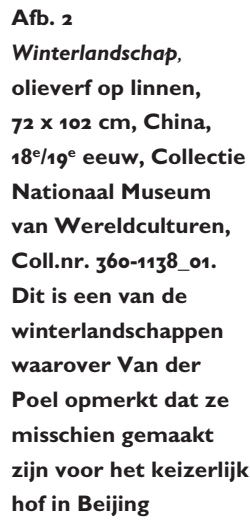

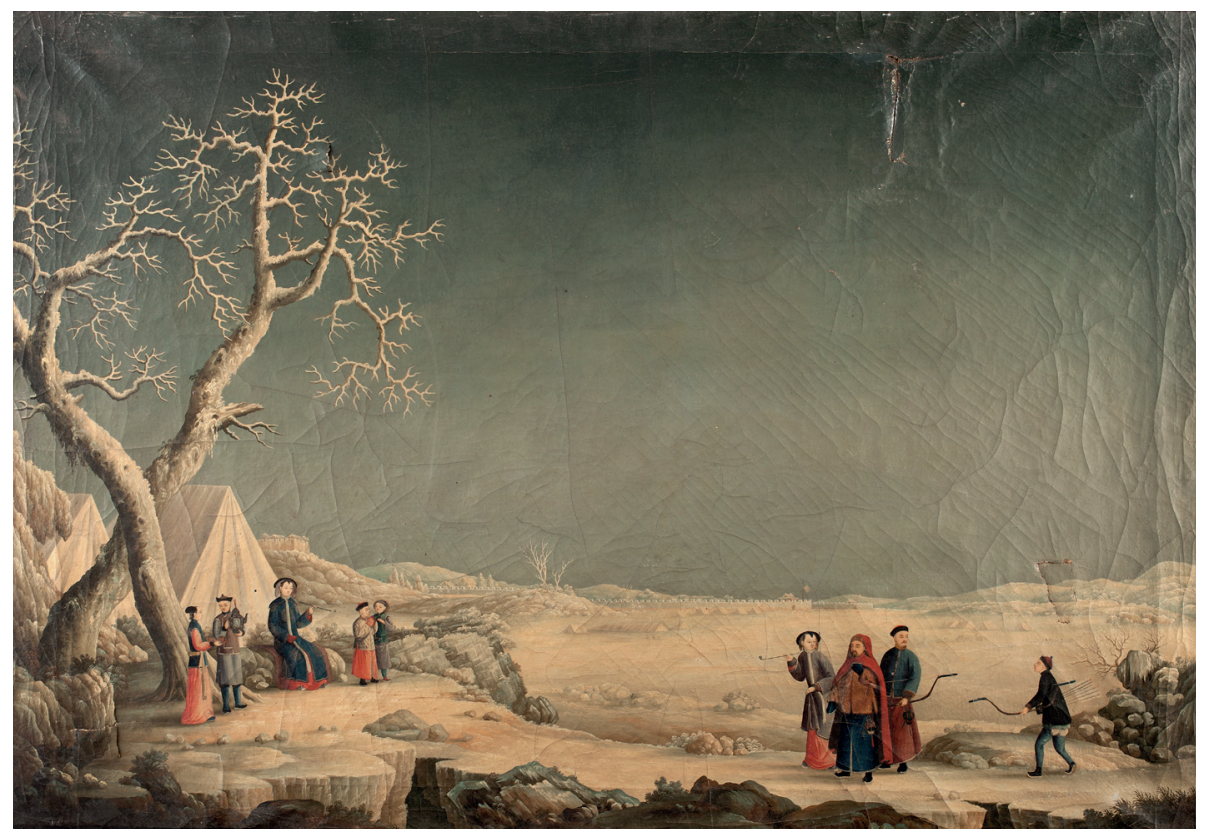

maar ook in Beijing, aan het hof. De belangstelling van het hof voor Europese schilderkunst was groot en jezuïeten-kunstenaars kwamen graag aan de vraag naar Europese kunstwerken tegemoet. Hofschilders in Beijing konden uit Kanton afkomstig zijn, een aantal jaren in de hoofdstad werken, en na verloop van een aantal jaren weer terugkeren naar ZuidChina. Zij kunnen gemakkelijk de kennis van de Europese schilderkunst die zij daar hadden opgedaan, naar Kanton mee hebben gebracht. Een van de meest intrigerende opmerkingen in het proefschrift is dat een aantal van de winterlandschappen misschien vervaardigd is voor het Hof in Beijing. Dat zou nog eens wat zijn! Keizerlijke schilderingen in Museum Volkenkunde. Er moet nog wel onderzoek verricht worden voor deze veronderstelling hard gemaakt kan worden. Maar juist op het punt van de winterlandschappen zijn onze verwachtingen van Rosaliens voortzetting van haar werk hoog gespannen. De bevestiging van deze keizerlijke herkomst is één punt. Het andere is de restauratie van deze werken. Want op het moment springen ze niet alleen in het oog door de wijze waarop ze de verbondenheid tonen van de Europese en Aziatische wereld aan het einde van de $18^{\mathrm{e}}$ eeuw, ze doen dat - zoals al gezegd - ook door hun bedroevende conditie. Vuil, schimmel, gaten en scheuren kenmerken deze doeken. Made for Trade heeft onomwonden het belang van deze schilderingen aangetoond. $\mathrm{Nu}$ is het de hoogste tijd ze hun oude visuele luister terug te geven. Rosalien: we rekenen op je.

- Rosalien van der Poel, Made for Trade - Made in China. Chinese export Paintings in Dutch Collections: Art and Commodity, Leiden, uitg. in eigen beheer, 20I6, 285 blz., ca. 250 fc ill., geb. IsB N 978-90-8I9129-2-I.

- Jan van Campen is conservator Aziatische exportkunst bij het Rijksmuseum. 